\title{
Some aspects of the state of the art of contaminated sites remediation in Italy
}

\section{Alcuni aspetti dello stato dell'arte della bonifica dei siti contaminati in Italia}

Giovanni Pietro Beretta

Riassunto: La bonifica dei siti contaminati è stata affrontata in Italia come nel resto del mondo con una successione di interventi originata dalla disponibilità di tecnologie specifiche per il recupero della qualità dei suoli e delle acque sotterranee, agendo secondo il principio di sostenibilità.

Si premette innanzitutto un inquadramento delle norme (valori limite e tipologia di interventi) e una sintesi della qualità dei suoli e delle acque sotterranee nei siti contaminati italiani.

La progettazione della bonifica è stata consentita anche dal miglioramento della caratterizzazione del sito, con apparecchiature specifiche indirizzate ad esempio ad individuare la stratigrafia dei contaminanti, la presenza di composti volatili, il prelievo di campioni di acque significativi della qualità delle acque sotterranee, etc..

Nel testo sono descritti alcuni interventi relativi a barriere fisiche e barriere idrauliche che comportano consistenti costi di investimento e di gestione ed anche il consumo di risorse naturali.

Successivamente si considerano anche importanti interventi in situ che hanno determinato una riduzione delle concentrazioni e un recupero significativo di massa di inquinanti.

Parole chiave: bonifica, messa in sicurezza, interventi in situ, concentrazione e massa di inquinanti.

Keywords: remediation, emergency measures, in situ interventions, pollutants concentration and mass.

Giovanni Pietro BERETTA 恝:

Università degli studi di Milano

Dipartimento di Scienze della Terra "Ardito Desio"

giovanni.beretta@unimi.it

Ricevuto: 10 aprile 2015 / Accettato: 30 maggio 2015

Pubblicato online: 30 giugno 2015

This is an open access article under the CC BY-NC-ND license: http://creativecommons.org/licenses/by-nc-nd/4.0/

(C) Associazione Acque Sotterranee 2015
L'evoluzione delle concentrazioni residue nelle acque sotterranee deve essere considerato mediante monitoraggio dell'attenuazione naturale.

Nonostante un recupero di inquinanti fino al 90-99\% della massa, non si possono raggiungere limiti di bonifica stabiliti dalla norma nazionale (valori attesi dell'ordine del $\mu \mathrm{g} / \mathrm{L}$ ).

E' quindi auspicabile che la comunità scientifica consideri un nuovo paradigma consistente in "ordine di grandezza del flusso di massa inquinante" che sostituisca il vecchio paradigma consistente in "valori limite finale delle concentrazioni".

Abstract: The remediation of contaminated sites has been faced in Italy and elsewhere in the world with a series of works originated by the availability of specific technologies for the recovery of soils and groundwater quality, acting in accordance with the principle of sustainability. A framework of rules (target values and type of intervention) and a summary of the quality of soil and groundwater in Italian contaminated sites must be mentioned first.

The design of the remediation was also permitted by the improvement of the site characterization, with specific equipments addressed for example to identify the stratigraphy of the contaminants, the presence of volatile compounds, the sampling of water of significant groundwater quality, etc.. The text describes some interventions relating to physical and bydraulic barriers that involve substantial capital and OEM costs and also the consumption of natural resources.

Subsequently they are also considered important in situ interventions that resulted in a reduction in the concentration and significant recovery of the pollutants mass.

The evolution of the residual concentration in the groundwater must be considered by monitoring natural attenuation.

Despite the recovery of the mass of pollutants even up to 90-99\%, values of cleanup (expected concentrations of the order of $\mu g / L$ ) which are established by national legislation have not been achieved.

It can be stated that the scientific community is considering the new paradigm expressed by the "order of magnitude of the flow of pollutant mass" to replace the old paradigm consisting in the "limit value of final concentrations". 


\section{Introduction}

From nearly forty years at the international level and thirty years in Italy, the problem of soil and groundwater remediation has been faced in order to ensure the use of the territory under conditions compatible with human health and the respect for environment, in areas of very different sizes and geology.

The difficulty of the problem is mainly related to:

- the knowledge of a complex and heterogeneous environment;

- the different behaviour of contaminants (solubility, volatility, biodegradability, etc.)

- the measurement of chemical-physical low values with complicated techniques in field and in laboratory:

- the application of traditional and innovative technologies;

- the achievement of very low target concentrations;

- the knowledge, sometimes limited, of the relationship between human health and environmental conditions.

At a first stage, the approach to the problem was to consider the contaminated soil as a waste to be confined in landfill and groundwater as discharge.

At a second stage the remedial actions and emergency measures were achieved by the application of traditional hydraulic and geotechnical techniques (pump and treat, vertical engineering barrier, capping).

At a third current stage the evolution of the remediation industry applies the recycle, reuse, transform and biodegrade criteria of in situ interventions (Hellis D.E., Hadley P.W. 2009).

The Italian law (D.Lgs.152/2006 and D.Lgs.4/2008) provides for soil two limit values: a screening value (in Italian "concentrazione soglia di contaminazione" - CSC), also considering the background values, for a) residential and green use, b) industrial and commercial use, and remediation targets established by means of risk analysis. ("concentrazione soglia di rischio" - CSR).

The fill is also considered, with assessment of possible release to groundwater through tests of their elution.

For groundwater the screening and remediation target (CSC) are the same and with very low values.

The interventions in contaminated sites are well summarized in space and in time by the law:

- Emergency measures (in Italian "messa in sicurezza d'emergenza"): interventions to prevent further contaminant migration in the environment;

- Operational emergency measures ("messa in sicurezza operativa”): provisional measures pending the cleanup in sites with industrial activities;

- Adjective confinement ("messa in sicurezza permanente"): permanent confinement of polluted environmental matrices or wastes.

- Cleanup ("bonifica”): intervention to reach the final targets values of soil and groundwater remediation.

\section{Soil and groundwter pollutants in remediation sites}

In Italy a three type of contaminated site are present.

1. Sites of National Interest ("Siti di interesse nazionale" SIN) - are sites (private end/or public) of high surface area, and with many and important pollutants from environmental and toxicological point of view; the Table 1 summarizes the sites currently affecting a surface of more than $2000 \mathrm{~km}^{2}$.

2. Regional sites SIR - are sites (private and/or public) generally of smaller surface involving the municipalities, with some pollutants and wastes.

3. Municipal sites SIC - are sites generally private, of limited surface and with few pollutants.

The Table 2 summarizes the remediation sites in Italy and the state of cleanup.

As part of the SIN the Environment Ministry, in the period 2001-2012, made available approximately 1887 M€ for interventions of public interest; in the same period they were approved by decree some 250 projects of private initiative, for an amount of about $1709 \mathrm{M} €$.

With regard to the sources of pollution, in Italy it prevails the treatment/disposal of waste, industrial, and commercial activities more than in Europe, probably related to poor national management of waste and absent or non-compliance with regulations in the course of production activities prior.

Additional contributions can be given with respect to substances released to the environment and that are involved in the application of remediation technologies.

The figure 1 shows how in soils it is present a larger component of heavy metals, chlorinated hydrocarbons and polycyclic aromatic hydrocarbons.

Figure 2 concerning groundwater, identifies a higher frequency for chlorinated hydrocarbons and BTEX, probably in connection with the difficulties of identifying these compounds in soils because of their volatility and the consequent need for adoption of specialized investigation of characterization.

On the families of pollutants classified treatment technologies provided in figure 3 were applied in Italy. Although the survey sample is limited to certain Regions and then also descriptive of a "treatment train", is observed as yet recently the activities of ex situ treatment covering $75 \%$ of the interventions, with a large and prevalent component landfilling.

\section{Improvement of site charaterization}

It has been proposed by the US Environmental Protection Agency a new approach for the characterization of contaminated sites that was also taken by European and Italian researchers (Kästner M. et al. 2012) based on three criteria: systematic project planning, dynamic work strategies and real-time measurement technologies (TRIAD approach).

To apply these criteria they should be adopted new investigation technologies overcoming the limitations of traditional ones; they are explained below some of these new technologies used at the national level, although currently small in number. 
Tab. 1 - Site of National Interest (SIN) for remediation in Italy: (*) Site later removed.

Tab. 1 - Siti di Interesse Nazionale (SIN) per la bonifica in Italia: (*) Sito successivamente rimosso.

\begin{tabular}{|c|c|c|}
\hline Region & SIN & Surface (ha) \\
\hline Abruzzo & Fiumi Saline e Alento (*) & 1.915 \\
\hline \multirow{2}{*}{ Basilicata } & Tito & 314 \\
\hline & Area industriale Val Basento & 3.393 \\
\hline Calabria & Crotone - Cassano e Cerchiara & 2.318 \\
\hline \multirow{5}{*}{ Campania } & Litorale Domitio Flegreo ed Agro Aversano (*) & 670 \\
\hline & Area del litorale Vesuviano (*) & 8.121 \\
\hline & Coroglio Napoli Bagnoli & 961 \\
\hline & Bacino Fiume Sarno (*) & (39 comuni) \\
\hline & Pianura $(*)$ & 156 \\
\hline \multirow{2}{*}{ Emilia Romagna } & Sassuolo-Scandiano $(*)$ & (9 comuni) \\
\hline & Fidenza & 26 \\
\hline \multirow{2}{*}{ Friuli Venezia Giulia } & Trieste & 1.698 \\
\hline & Laguna di Grado e Marano & 11.029 \\
\hline \multirow{2}{*}{ Lazio } & Frosinone $(*)$ & (85 comuni) \\
\hline & Bacino Fiume Sacco $(*)$ & (9 comuni) \\
\hline \multirow{3}{*}{ Liguria } & Cengio e Saliceto & 22.228 \\
\hline & La Spezia - Pitelli (*) & 22.045 \\
\hline & Cogoleto & 212 \\
\hline \multirow{7}{*}{ Lombardia } & Sesto San Giovanni & 255 \\
\hline & Btescia Caffaro & 262 \\
\hline & Laghi di Mantova e Polo Chimico & 1.028 \\
\hline & Broni & 14 \\
\hline & Pioltello e Rodano & 84 \\
\hline & Cerro al Lambro (*) & 6.193 \\
\hline & Milano Bovisa (*) & 43 \\
\hline \multirow{2}{*}{ Marche } & Basso Bacino Fiume Chienti (*) & 3.832 \\
\hline & Falconara Marittima & 1.274 \\
\hline Molise & Guglionesi II (*) & 8 \\
\hline \multirow{5}{*}{ Piemonte } & Casale Monferrato & 73.834 \\
\hline & Balangero & 314 \\
\hline & Pieve Vergonte & 15.148 \\
\hline & Torino - Basse di Stura $(*)$ & 8.785 \\
\hline & Serravalle Scrivia & 74 \\
\hline \multirow{4}{*}{ Puglia } & Manfredonia & 1.156 \\
\hline & Brindisi & 11.323 \\
\hline & Taranto & 11.374 \\
\hline & Bari & 15 \\
\hline \multirow{3}{*}{ Sardegna } & Sulcis-Iglesiente-Guspinese & (34 comuni) \\
\hline & Area industrial Porto Torres & 4.571 \\
\hline & La Maddalena (*) & \\
\hline \multirow{4}{*}{ Sicilia } & Gela & 5.358 \\
\hline & Priolo & 13.451 \\
\hline & Biancavilla & 339 \\
\hline & Area industriale Milazzo & \\
\hline \multirow{5}{*}{ Toscana } & Piombino & 2.842 \\
\hline & Massa e Carrara & 3.537 \\
\hline & Livorno & 2.072 \\
\hline & Orbetello & 335 \\
\hline & Ex discarica Strillaie $(*)$ & \\
\hline Trentino Alto Adige - Trento & Trento & 24 \\
\hline Trentino Alto Adige Bolzano & Bolzano $(*)$ & 27 \\
\hline Umbria & Terni-Papigno & 655 \\
\hline Valle d'Aosta & Emarese & 15 \\
\hline \multirow{2}{*}{ Veneto } & Porto Marghera & 5.790 \\
\hline & Ceregnago Mardimago (*) & 57 \\
\hline
\end{tabular}


Tab. 2 - Cleanup of contaminated site in Italy by Region: update to 2013 (Beretta G.P. 2013).

Tab. 2 - Bonifica di siti contaminati in Italia suddivisi per Regione: aggiornamento al 2013 (Beretta G.P. 2013).

\begin{tabular}{|c|c|c|c|c|c|}
\hline $\begin{array}{l}\text { Region/ } \\
\text { Province }\end{array}$ & $\begin{array}{c}\text { Virtually } \\
\text { contaminated sites }\end{array}$ & $\begin{array}{c}\text { Contaminated sites } \\
\text { found }\end{array}$ & Contaminated sites & $\begin{array}{c}\text { Sites with ongoing } \\
\text { actions }\end{array}$ & Cleanup sites \\
\hline Piemonte & 1315 & 402 & 466 & 1171 & 146 \\
\hline Valle d'Aosta & - & 14 & 12 & 15 & 22 \\
\hline Liguria & - & 81 & 119 & 78 & 50 \\
\hline Lombardia & 3970 & 1879 & 853 & - & 1238 \\
\hline Trento & - & 31 & 86 & 86 & 351 \\
\hline Bolzano & - & - & 272 & & 114 \\
\hline Veneto & 541 & 181 & 87 & 376 & 55 \\
\hline Friuli-Venezia-Giulia & 684 & 229 & - & - & 94 \\
\hline Emilia Romagna & ND & 225 & 323 & 343 & 331 \\
\hline Toscana & 2826 & 477 & 1050 & 324 & 257 \\
\hline Umbria & 120 & 44 & 64 & 64 & 12 \\
\hline Marche & 673 & 81 & 297 & 741 & 295 \\
\hline Lazio & 887 & 621 & 71 & 798 & 18 \\
\hline Abruzzo & - & - & - & - & - \\
\hline Molise & - & - & 2 & 3 & 0 \\
\hline Campania & 2592 & 359 & 183 & 73 & 12 \\
\hline Puglia & 298 & 98 & 200 & 152 & 1 \\
\hline Basilicata & - & 316 & 6 & 190 & 3 \\
\hline Calabria & ND & 646 & 52 & 18 & 7 \\
\hline Sicilia & 642 & 45 & - & 347 & 0 \\
\hline Sardegna & 574 & 403 & 171 & 100 & 5 \\
\hline ITALY & 15122 & 6132 & 4314 & 4879 & 3011 \\
\hline
\end{tabular}



Fig. 1 - Soil pollutants in Europe and in Italy (EIONET 2007, 2014; Beretta G.P. 2013).

Fig. 1 - Inquinanti del suolo in Europa e in Italia (EIONET 2007, 2014; Beretta G.P. 2013)

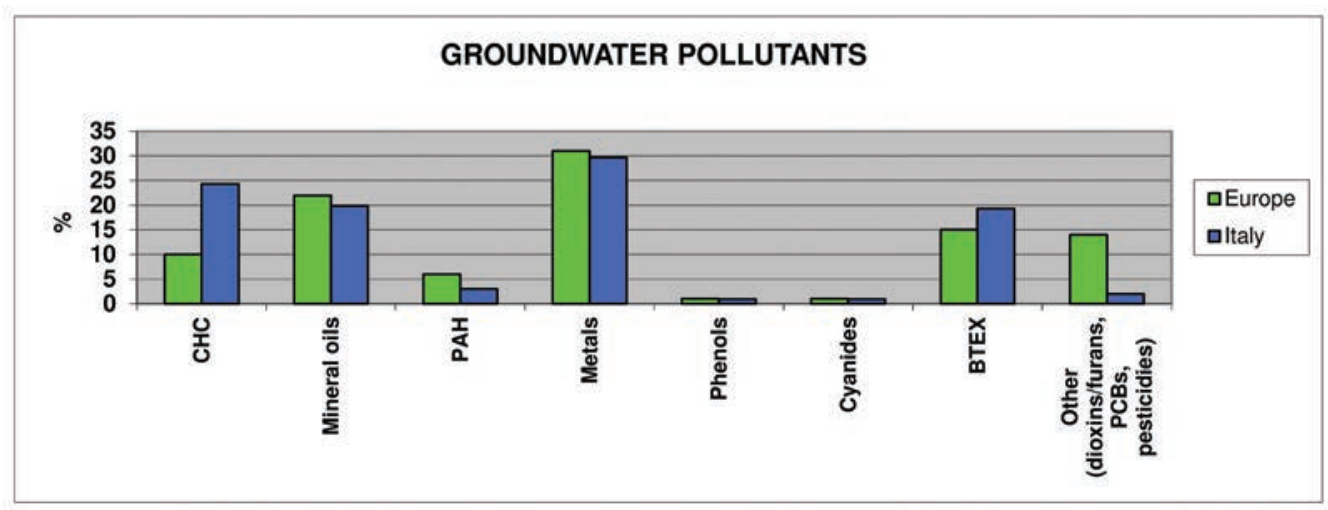

Fig. 2 - Groundwater pollutants in Europe and in Italy (EIONET 2007, 2014; Beretta G.P. 2013)

Fig. 2 - Inquinanti delle acque sotterranee in Europa e in Italia (EIONET 2007, 2014; Beretta G.P. 2013) 


\section{REMEDIATION TREATMENT IN ITALY}

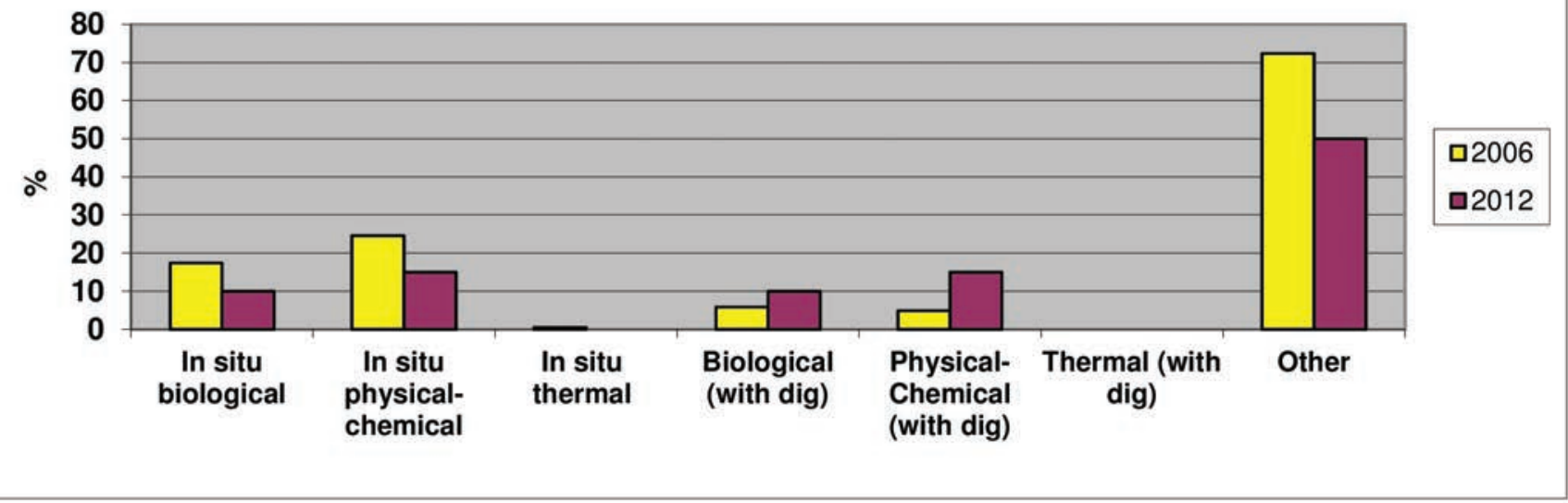

Fig. 3 - Soil and groundwater remediation system in Italy (Beretta G.P. 2013).

Fig. 3 - Sistemi di bonifica di siti contaminati in Italia (Beretta G.P. 2013).

The use was also applied during the remediation, and not only in the initial cognitive stage, to study for example the problems of cross contamination through a natural barrier due to foundation piles construction, the equivalent hydraulic conductivity of sheet piles.

The migration of substances injected in subsoil for reacting with pollutants, the losses from old discharges, the indoor/outdoor concentration of VOC, etc..

Ground penetration radar is used to identify conductive plumes of free phase liquid, Electromagnetic induction, Electrical impedance tomography and Self Potential for detection of contaminant and utilities in subsoil.

The geophysical methods have been applied not only in aid to geological surveying, but in the clean phase as the elettrotomography an Georadar methods in the control the in situ chemical reduction (ISCR) of hexavalent Chromium in Spinetta Marengo plant (AL) due to injection of Sodium dithionite $\left(\mathrm{Na}_{2} \mathrm{~S}_{2} \mathrm{O}_{4}\right)$.

A probe MIHPT, a combination probe derived from direct push technology, that can perform membrane interface probe (MIP) and injection pressure of water (HPT) are used and maximum investigation depth of $30 \mathrm{~m}$ was verified in Milan.

A typical log acquired with the MIHPT system (Fig. 4) can be shown Electrical Conductivity $(\mathrm{mS} / \mathrm{m})$, Flow $(\mathrm{mL} /$ $\min )$, Pressure $(\mathrm{kPa})$, PID $\max \left(\mu \mathrm{V} \cdot 10^{6}\right)$ and $\mathrm{K}(\mathrm{m} / \mathrm{day})$

This information is used to recognize the subsoil heterogeneity and the contaminant stratigraphy, especially the VOC concentration, for the better characterization and the cleanup design. In addition, a free phase of DNAPL was identified at the base of a sandy aquifer.

The flow of VOC in the unsaturated media with flux chamber was monitored to verify the results of risk analysis and to support theoretical analytical model.

A low flow method of groundwater sampling is now widely used to sample the water in the geological media with low permeability and to obtain samples free of sediments, with the need for filtration of the water.

Vertical measurement with flowmeter heat-pulse tests and multilevel sampling are very rare (Petitta M. et al. 2012).

A traditional method of hydrocarbon fingerprinting was applied to evaluate hydrocarbon degradation in the Trecate (NO) crude oil spill.

A blow-out occurred at the Eni -Agip crude oil well TR-24 released $12,600 \mathrm{~m}^{3}$ of light sweet crude oil, 1,000,000 $\mathrm{m}^{3}$ of natural gas and $1,000 \mathrm{~m}^{3}$ of water into the environment.

After on site and in situ remediation works (pumping of residual free oil phase, polluted soil excavation, biopiles, landfarming, bioventing, biosplurping, phase -separated hydrocarbons recovery, thermal desorption) a monitoring natural attenuation program, which lasts for several years, was applied.

The use of a "line 2" of monitoring natural attenuation MNA (American Society for Testing and Materials, 1998, U.S. Environmental Protection Agency, 1997) has shown that the dissolved hydrocarbon plume seems stable and controlled via aerobic and anaerobic bacterial degradation; as expected the electron acceptors such as Oxygen, Nitrates and Sulphates are depleted and ferrous Iron and Sulphides are produced.

The monitoring activities is very important to control the transport of pollutants and the presence downgradient of receptors, for example in hexavalent Chromium plumes $3-4 \mathrm{~km}$ long in the Bergamo plain.

At last the hydrocarbon fingerprinting gas chromatography underline a hump in the baseline due to unresolved residual 


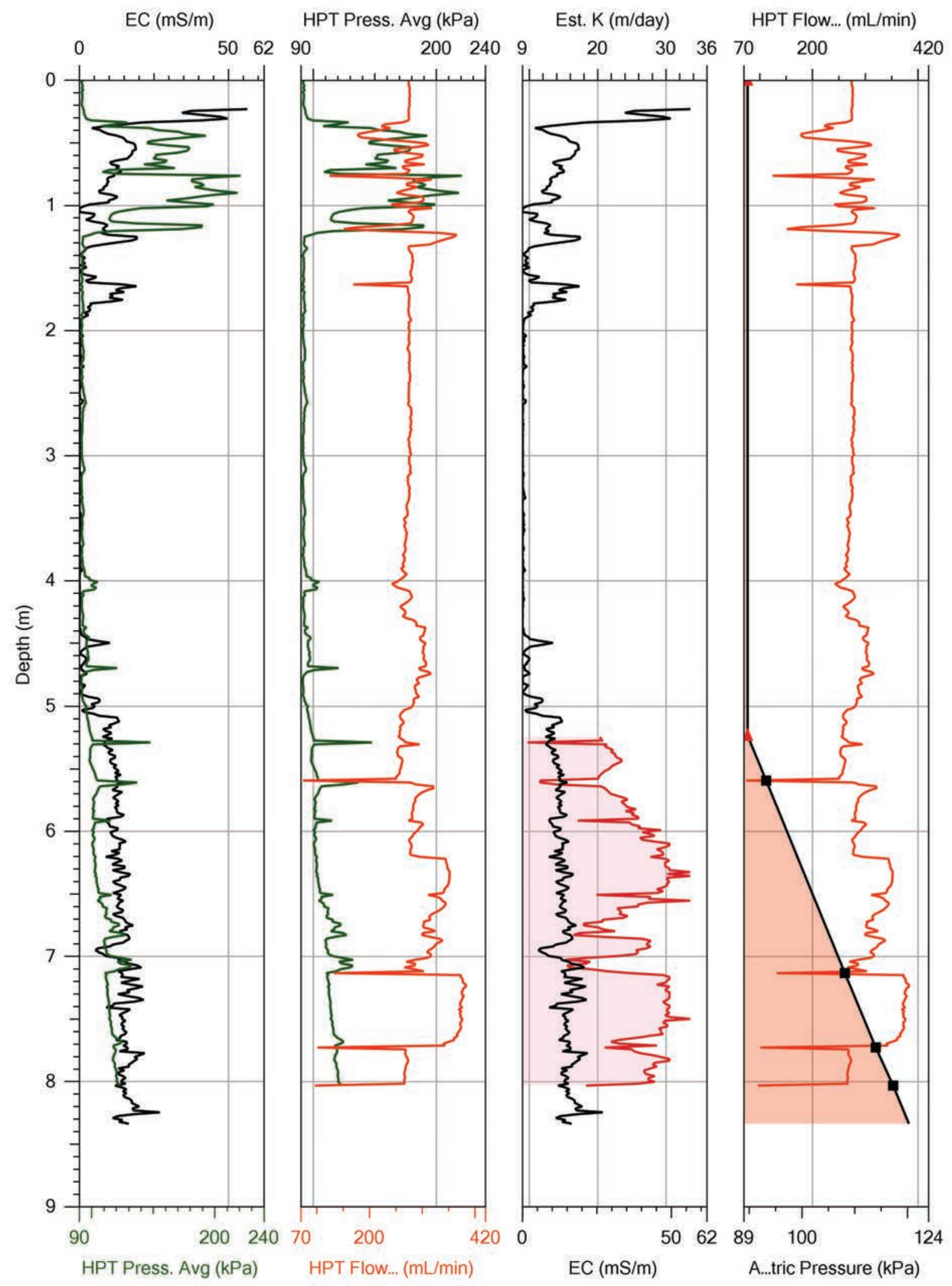

Fig. 4 - An example of MIHPT log (from courtesy of INFOGEO Srl).

Fig. 4 - Un esempio di log MIHPT (per concessione di INFOGEO Srl). 
complex mixture of difficult biodegradation.

The isotopic fingerprinting, especially for Carbon, was applied to know better the pollutants transport and the biodegradation of Chlorinated compounds for example in Ferrara (Shouakar-Stash O. et al. 2009) or Chienti river (Petitta M. et al. 2012); difficulties with an extensive and desirable use is due to lack of analytical laboratories in Italy.

These techniques, defined compounds-specific isotope analysis (CSIA), exploit the enrichment of heavier isotopes (for example ${ }^{13} \mathrm{C}$ respect ${ }^{12} \mathrm{C}$ ) in the residual contaminant fraction and their depletion in the degradation product due to microbial activities.

Biogeochemical techniques have been developed at the IRSA-CNR in Monterotondo (Roma) and applied for special cases of contaminated site (Rossetti S. et al. 2008a and 2008b).

These techniques, described for example in Kaster M. et al. 2012, are the BACTRAPs and FISH and CARD-FISH.

In the BACTRAPS the composition of bacteria exposed to groundwater colonising an in situ microcosm area analysed, highlighting the potential of pollutants degradation.

The Fluorescent I-situ Hybridization techniques (FISH and CARD-FISH) in combination with the quantitative real-time Polymerase Chain Reaction (qPCR) area used for quantify the dechlorating microorganism, the individual microbial cells and potential active microorganisms.

The organic compounds undergo a degradation in an aerobic and anaerobic environment and this transformation can be mediated by microorganisms (biotic) or by chemical reaction (abiotic).

For example the microorganisms involved in the anaerobic degradation of chlorinated solvents are Dehalococcoides ethenogenes strain 195 (PCE to ethylene) and Dehalobacter sp (PCE to cis-DCE) (U.S. Environmental Protection Agency, 2006).

An extensive use of these techniques are desirable, also for operational purpose and not only scientific laboratory.

A series of guidelines have been proposed to carry out the characterization investigations (APAT 2006a, 2006b; Provincia di Milano-Università degli studi di Milano 1999, 2003b, 2003d, 2004b, 2006a, 2006b).

\section{Engineering vertical barriers}

Many initial interventions on contaminated sites have designed and implemented superficial barriers and diaphragms.

The latter in the case of Cengio and Saliceto (the first area of national interest) were made to separate the area with the waste disposal from the area reused for industrial purpose, with the unitary cost of cutoff wall of $400 € / \mathrm{m}^{2}$.

In Venice the "macroisole" in the industrial area of Porto Marghera are being completely confined from the lagoon with diaphragms and sheet piles, with extension of tens of kilometres at the cost of about $12 \mathrm{M} € / \mathrm{km}$.

Within the confined area, groundwater drains are made to capture and treat the contaminated water and keep the hydraulic head lower than the external.

In many other sites were made the engineering barriers (Gela, Priolo, etc.) that leave an almost perennial constraint for land reuse.
Their use is more justified in the presence of many soil contaminants with different chemical, physical and biological behaviour and or the waste.

An important and big realization is made for the confinement of the old landfill in Manfredonia (FG) based on the isolation of the body and the bottom, reducing the permeability of limestone below the facility.

These interventions have been conducted working from the surface (outside the landfill perimeter) with horizontal directional drilling (HDD) with a $130 \mathrm{~m}$ long (Commissario Delegato 2011).

A guideline for design and verification of barriers are proposed in Italy by Provincia di Milano-Università degli studi di Milano, 2003a.

The thickness and the hydraulic conductivity of the barrier must comply with some criteria that can be derived from Italian law (D.Lgs. 36/2003 "Implementation of Directive 1999/31 / EC on the landfill of waste") and scientific literature:

- minimum thickness: $0.5 \mathrm{~m}$;

- minimum crossing time of a barrier with a thickness of $5 \mathrm{~m}$ and hydraulic conductivity equal to $10^{-9} \mathrm{~m} / \mathrm{s}$ in the case of the adoption of an equivalence to a hazardous waste in the landfill (corresponding to approximately 158.5 years);

- unitary flow rate of the filtration system, under unitary hydraulic gradient, of: $1.71 \div 6.83 \mathrm{~L} / \mathrm{m}^{2} /$ year (U.S. Environmental Protection Agency, 1984 and 1988);

- minimum depth of clamping designed based on the time of crossing minimum expected, corresponding to a thickness of $5 \mathrm{~m}$ and hydraulic conductivity equal to $10^{-9} \mathrm{~m} / \mathrm{s}$.

To verify the thickness of the vertical barrier we can refer to the following relationship:

$$
b=\sqrt{\frac{k_{d} \Delta H}{n_{d}} t_{a}}
$$

In which:

$b$ : thickness of vertical barrier $(\mathrm{m})$;

- $\quad k_{d}$ : hydraulic conductivity of the vertical barrier $(\mathrm{m} / \mathrm{s})$;

- $\quad \Delta H$ : hydraulic head difference between inner and outer zone of the vertical barrier $(\mathrm{m})$;

- $\quad n_{d}$ : effective porosity of vertical barrier:

- $t_{a}$ : crossing time (s).

The clamping depth c (m) of vertical barrier in the substrate can be evaluated by means the following relationship:

$$
c=\frac{1}{2} \cdot\left[t_{a} \cdot \frac{k_{s} \Delta H}{b n_{s}}-b\right]
$$


In which:

- $\quad k_{s}$ : hydraulic conductivity of the substrate $(\mathrm{m} / \mathrm{s})$;

- $\quad n_{s}$ : effective porosity of the substrate.

Finally, to verify the hydraulic head difference in the design $(\Delta \mathrm{H})$ can be apply the relationship:

$$
\Delta H=-\ln \frac{C}{C_{0}}\left(\frac{n_{d} D}{k_{d}}\right)
$$

in which:

- $\quad C$ : concentration at the time $\mathrm{t}(\mathrm{mg} / \mathrm{L})$;

- $\quad C_{0}$ : initial concentration $(\mathrm{mg} / \mathrm{L})$;

- $\quad D$ : diffusion coefficient $\left(\mathrm{m}^{2} / \mathrm{s}\right)$.

In this way it is possible to hinder also the molecular diffusion $\left(10^{-10} \mathrm{~m}^{2} / \mathrm{s}\right.$ in groundwater), which might result in the escape of contaminants from the confined zone, although in low concentrations.

During the barrier construction the tests are also aimed at verifying the values of hydraulic conductivity of the wall.

Because the scale-effect, the values obtainable from laboratory tests are lower than those in the field (Fig. 5), which are therefore preferable.
Similar experiences are reported in the scientific literature concerning the tests inside the diaphragm by means of slug tests (Choi H., Daniel, D.E. 2006a and 2006b; Nguyen T.B et al. 2010) and other hydraulic tests (Britton J.P et al. 2002; Teeter R.M., Clemence S.P. 1986)

Various tests after the completion of the works are available: hydraulic stress (pumping test with piezometric controls inside and outside the confined area), geophysical methods, piezocone test (CPTU) and laboratory test on slurry wall samplings.

A tracer test with $\mathrm{LiCl}$ was carried out to evaluate the performance of the seal in sheet piles in Porto Marghera industrial area.

Modelling of slurry wall containment are made by Choi $\mathrm{H}$. 2007 and Pedretti D. et al. 2012

A further aspect is the durability of the barriers, on which we have an insufficient experimental data.

In the Table 3 they are proposed the lifetimes of some materials used for the engineering barriers (Inyang H.I., Tomassoni G. 1992); according to the Authors, it seems that in about 30 years of life, some systems are inefficient.



Hydraulic conductivity $(\mathrm{m} / \mathrm{s})$

Fig. 5 - Example of laboratory and in situ test for hydraulic conductivity measurement of slurry wall (Chini A. et al. 2002).

Fig. 5 - Esempio di misura in laboratorio e in situ della conducibilità idraulica di un diaframma in cemento bentonite (Chini A. et al. 2002). 
Tab. 3 - Estimated long-term effectiveness of selected waste containment measures: aassumes addition of new cap at 100 years, b-assumes addition of new synthetic cap at 100 years, c-assumes addition of new composite clay and synthetic cap at 100 years, $d$-assumes addition of new HDPE at 100 years, e-assumes addition of new slurry wall at 30 years (Inyang H.I., Tomassoni G. 1992).

Tab. 3 - Efficacia stimata a lungo termine di alcuni sistemi di confinamento di rifiuti: a - si assume un'aggiunta di una nuova copertura a 100 anni; b - si assume un'aggiunta di una nuova copertura artificiale a 100 anni, c - si assume un'aggiunta di una copertura composita in argilla e artificiale a $100 \mathrm{anni,} \mathrm{d}-\mathrm{s}$ assume un'aggiunta di una geomembrana in HDPE a 100 anni, e - si assume un'aggiunta di un diaframma in cemento bentonite a 30 anni (Inyang H.I. Tomassoni G. 1992)

\begin{tabular}{|l|c|c|c|c|}
\cline { 2 - 5 } \multicolumn{1}{c|}{} & \multicolumn{4}{c|}{ Indexing Time Increment (t years) } \\
\hline Effectiveness $(\%)$ & $\mathrm{t}_{0}$ & $\mathrm{t}_{10}$ & $\mathrm{t}_{30}$ & $\mathrm{t}_{100}$ \\
\hline Clay cap & 80 & 75 & 60 & $20(85 \mathrm{a})$ \\
\hline Synthetic cap & 90 & 85 & 75 & $15(90 \mathrm{~b})$ \\
\hline Clay plus synthetic cap & 95 & 92 & 80 & $35(98 \mathrm{c})$ \\
\hline RCRA C composite liner system & 98 & 95 & 85 & 60 \\
\hline Clay liner & 70 & 60 & 40 & 5 \\
\hline Synthetic liner & 85 & 75 & 35 & 0 \\
\hline HDPE wall & 65 & 60 & 50 & $25(65 \mathrm{~d})$ \\
\hline Slurry wall & 70 & 60 & $20(70 \mathrm{e})$ & 0 \\
\hline
\end{tabular}

\section{Hydraulic barriers}

The hydraulic barriers have been used in Italy from the seventies in urban areas to prevent the spread of pollutants plumes toward wells for drinking water.

The polluted groundwater, withdrawal by trenches or wells, has had 1) an uncertain classification from the regulatory point of view: waste or discharge, 2) an uncertain treatment goals (target value in exit to plants), 3) a possibility of injecting water into subsoil.

For point 1) a decision was taken considering discharge the direct water shipment to a facility for treatment of water by means of pipeline dedicated, otherwise water is considered waste.

For point 2) various criteria have been proposed:

- Treatment of water

- Possible reuse of water in situ (industrial areas)

- Measure in mass of pollutants values discharged

In any case, the treatment should ensure an effective reduction of pollutant loads released into the environment.

For point 3) emphasis can be reserved at the European Directive 2000/60/EC that in the "Article 11 - Programme of measures" provides:

"Member States may authorize reinjection into the same aquifer of water used for geothermal purposes.

They may also authorise, specifying the conditions for: .........

Discharges of small quantities of substances for scientific purposes for characterization, protection or remediation of water bodies limited to the amount strictly necessary for the purposes concerned.

Provided such discharges do not compromise the achievement of the environmental objectives established for that body of groundwater."
The Italian law 98/2013 has incorporated these principles.

Another important problem concerns the location of the "point of compliance" of groundwater quality downgradient that is established primarily to property line of the contaminated site.

We can also consider other criteria if have background values higher or if have defined quality goals less restrictive on the Water Protection Plan.

Various layout patterns of wells with the pump and treat (P\&T) function have been made: in the source of contamination, along the plume, at the property limit.

The horizontal directional drilling (HDD) were made in Porto Marghera (Venise) in a thin polluted sandy aquifer with low flow rate (about order of magnitude of $\mathrm{L} / \mathrm{s}$ ).

Matrix diffusion and back diffusion influence the ability to restore groundwater quality in source zones and in plumes.

For compounds while chlorinated solvents the plume in first phase expanding in the trasmissive zones of subsoil, in the second phase expanding in the stagnant zones (less permeable) and in the third phase simultaneous inward and outward diffusion occurs in stagnant zones.

Important phenomena of tailing and rebound of concentration, in expected final cleanup is recorded in many cases, also due to very low target values, in some cases of the order of magnitude or less than the $\mu \mathrm{g} / \mathrm{L}$.

By convection, the rebound of concentration can be estimated by the following formula:

$$
R E B=\frac{\log \left(C_{r} / C_{f}\right)}{\log \left(C_{0} / C_{f}\right)}
$$

In which

- $\quad C_{r}=$ concentration at the end of monitoring time;

- $\quad C_{f}=$ concentration at the end of remediation;

- $C_{0}=$ concentration at the start of remediation:

- $\mathrm{REB}<0.2$ permanent concentration decrease,

- $0.2<\mathrm{REB}<0.5$ pursuance of the monitoring,

- $\mathrm{REB}>0.5$ : rebound of the concentration.

Furthermore high costs for the recovery of a limited mass of pollutant were employed also in agreement with literature data (Landesanstalt für Umwelt, Messungen und Naturschutz Baden-Württemberg 2012) for the recovery of poorly soluble substances.

For example in Pieve Vergonte (Verbania-Cusio-Ossola) a hydraulic barrier withdraws a rate of $350-850 . \mathrm{m}^{3} /$ day (seasonal flow rate of groundwater) and a plant unique in the world for the treatment also the DDT with capital cost of about $18 \mathrm{M} €$ required $\mathrm{O} \& \mathrm{M}$ cost of about $2 \mathrm{M} €$ for the recovery of $1.2 \mathrm{~kg} /$ year of the compound.

Seasonal withdrawal by wells is regulated by a computerized system based on piezometric levels.

In other cases, such as for hexavalent Chromium, they have been achieved very low values of remediation, in relation to the high solubility of this metal. 
In coastal contaminated sites (Manfredonia, Napoli-Bagnoli) a line of pumping wells was combined with a line of recharge wells downgradient to counteract active saline water encroachment due a general lowering of water table; the quality of recharge water (after treatment) must respect the target values provided by the law.

To verify the efficiency and effectiveness of hydraulic barriers they were also made available national guidelines (ISPRA 2003; Provincia di Milano-Università degli studi di Milano 2003c), that are also inspired by the numerous international experiences.

A simple statistic summarizes in Table 4 some costs of the cleanup works derived from 17 SIN in which an important total flow rate of $40.5 \mathrm{Mm}^{3} / /$ year is taken from groundwater, with an average of $6500 \mathrm{~m}^{3} /$ day for the single site.

Tab. 4 - Costs of some works in contaminated sites (Majone M. et al. 2009).

Tab. 4 - Costi di alcuni interventi in siti contaminati (Majone M. et al. 2009)

\begin{tabular}{|l|c|c|c|c|}
\hline \multicolumn{1}{|c|}{$\begin{array}{c}\text { Type of } \\
\text { work }\end{array}$} & $\begin{array}{c}\text { Average } \\
\text { depth } \\
(\mathrm{m})\end{array}$ & $\begin{array}{c}\text { Average } \\
\text { cost }\end{array}$ & $\begin{array}{c}\text { Unit of } \\
\text { measure }\end{array}$ & Range \\
\hline Well & 30 & 1.344 & $€ / \mathrm{m}$ & $600-2900$ \\
\hline Trench & $4-5$ & 755 & $€ / \mathrm{m}$ & $425-1500$ \\
\hline Well point & $4-5$ & 429 & $€ / \mathrm{m}$ & $400-505$ \\
\hline $\begin{array}{l}\text { Permeable } \\
\text { reactive barrier }\end{array}$ & 10 & 965 & $€ / \mathrm{m}^{2}$ & $* * * * *$ \\
\hline Sheet pile & 20 & 185 & $€ / \mathrm{m}^{2}$ & $139-316$ \\
\hline Slurry wall C/B & 20 & 280 & $€ / \mathrm{m}^{2}$ & $120-462$ \\
\hline Slurry wall C/B \\
+ HDPE
\end{tabular}

A problem of great impact on the management of groundwater resources is due to presence, as in Milano, of plumes of different pollutants.

It is therefore necessary to establish a classification of plumes (for priorities of intervention and risk evaluations) based on mass transport, as proposed by Neville C.J. et al. 2011 and modified to fit the national experience in Table 5.

\section{In situ treatment}

Numerous examples of application of in situ technologies are now also available in Italy, largely derived from the international approach to remediation soil and groundwater and following some significant experiences are described.

In large industrial areas, even partially abandoned, with refineries or fuel storage, traditional interventions of Soil Vapor Extraction (SVE), Air Sparging (AS), Multiphase Extraction (MPE), with systems of significant size are realized for treatment the petroleum hydrocarbons.
Tab. 5 - Plume classification with $C_{\text {receptor }}=1 \mu \mathrm{g} / \mathrm{L}$ (from Neville C.J. et al. 2011 modified)

Tab. 5 - Classificazione dei pennacchi con Crecettore $=1 \mu \mathrm{g} / \mathrm{L}$ (da Neville C.J. et al. 2011 modificato)

\begin{tabular}{|c|c|c|}
\hline $\begin{array}{l}\text { Mass disharged } \\
(\mathrm{g} / \text { day })\end{array}$ & $\begin{array}{l}\text { Class of } \\
\text { plume }\end{array}$ & $\begin{array}{l}\text { Flux condition that virtually } \\
\text { impact the wells or rivers }\end{array}$ \\
\hline$<0.001$ & "Mag 1Plume" & Limited impact \\
\hline 0.001 to 0.01 & $\begin{array}{l}\text { "Mag } 2 \\
\text { Plume" }\end{array}$ & Domestic well $\left(10 \mathrm{~m}^{3} /\right.$ day $)$ \\
\hline 0.01 to 0.1 & $\begin{array}{l}\text { "Mag } 3 \\
\text { Plume" }\end{array}$ & Water supply well $\left(100 \mathrm{~m}^{3} /\right.$ day $)$ \\
\hline 0.1 to 1 & $\begin{array}{l}\text { "Mag } 4 \\
\text { Plume" }\end{array}$ & Water supply well (1000 m³/gday) \\
\hline 1 to 10 & $\begin{array}{l}\text { "Mag } 5 \\
\text { Plume" }\end{array}$ & Water supply well $\left(10000 \mathrm{~m}^{3} /\right.$ day $)$ \\
\hline 10 to 100 & $\begin{array}{l}\text { "Mag } 6 \\
\text { Plume" }\end{array}$ & River base flow of $1.16 \mathrm{~m}^{3} / \mathrm{s}$ \\
\hline 100 to 1000 & $\begin{array}{l}\text { "Mag } 7 \\
\text { Plume" }\end{array}$ & River base flow of $11.6 \mathrm{~m}^{3} / \mathrm{s}$ \\
\hline 1000 to 10000 & $\begin{array}{l}\text { "Mag } 8 \\
\text { Plume" }\end{array}$ & River base flow of $115.7 \mathrm{~m}^{3} / \mathrm{s}$ \\
\hline 10000 to 100000 & $\begin{array}{l}\text { "Mag } 9 \\
\text { Plume" }\end{array}$ & River base flow of $1157.4 \mathrm{~m}^{3} / \mathrm{s}$ \\
\hline$>100000$ & $\begin{array}{l}\text { "Mag } 10 \\
\text { Plume" }\end{array}$ & River base flow $>1157.4 \mathrm{~m}^{3} / \mathrm{s}$ \\
\hline
\end{tabular}

An example of a Soil Vapor Extraction (SVE) of high performance has been designed on two depths of 20 and $60 \mathrm{~m}$ (above and below of a perched aquifer); a radius of influence in deep system has reached about $100 \mathrm{~m}$ with a flow rate of $290 \mathrm{~m}^{3} /$ day.

The mass of chlorinated solvents extracted in Cesano Maderno site (Milan) was $49.5 \mathrm{t}$ in the period 1997-2013.

In Bologna province a double system of in situ thermal treatment: was applied on the pollutant source $(10 \times 25 \mathrm{~m})$ : only steam injection in the West side of the source area and afterwards only electrical resistance heating in the Est side of the area:

After 110 days of remediation activities it was recovered a mass of about $970 \mathrm{~kg}$ of chlorinated solvents.

In industrial area of Brugherio (Milano) a soil flushing system with tap water were applied for removal hexavalent Chromium to soil, up to a depth of $22 \mathrm{~m}$ (Avanzini M. et al. 1994).

The mass removed by downgradient wells is $142 \mathrm{~kg}$ and a finishing of intervention was made with geochemical fixation (injection of dilute solution of $\mathrm{FeSO}_{4}$ ) to reduce $\mathrm{Cr}^{6+}$ in $\mathrm{Cr}^{3+}$.

Only few application of zerovalent Iron permeable reactive barrier were carried out in Italy; a first (Di Molfetta A., Sethi R. 2005 and 2006) was designed and realized to chlorinated solvents remediation in Avigliana (TO).

A first application of pollutant oxidation was for Acetone cyanohydrin (spill source of about $90 \mathrm{t}$ that degrades quickly the compound in cyanides) in Rho (Milan). 
In addition to a P\&T system pump, an injection of Hydrogen peroxide in a double line allowed to recover or degrade almost completely the compound (Avanzini M. et al. 1996); In figure 6 are represented the isopleth maps of cyanides and Hydrogen peroxide injected.

In recent years, a patented products and other specific compounds as Ozone, persulfates, Hydrogen Peroxide (Fenton) and permanganate were employed as pollutant degradation via oxidation reactions.

Other patented product were applied to produce reduction of pollutants; the application of whey (by-product of dairy industry) is an interesting application on hexavalent Chro mium plumes in Bergamo and Brescia provinces, even for lower costs, but with results still to be evaluated in depth. A whey permeate should be used, to prevent other unwanted reactions affecting Azote compounds.

Only a few Italian patents systems have been studied and applied for cleaning up: solidification of contaminated soils, extraction of the organic compounds from the soil by ethyl acetate, reduction of hexavalent Chromium by Hydrogen injection.

The application of the various remediation systems can be indicated by the statistics of the Lombardy Region, in which were performed many remediation of contaminated sites;
At the regional sites the interventions of dig and dump are $35.9 \%$ and interventions in situ to $30.76 \%$, with a $\mathrm{P} \& \mathrm{~T}$ to $12.82 \% ; 19$ sites have been reclaimed and 30 are yet contaminated.

In the municipal sites dig and dump increases to $62.01 \%$ while interventions in situ decrease to $22.78 \%$, with P\&T at $7: 41 \% ; 1282$ sites have been reclaimed and 766 are yet contaminated.

This situation for the municipal sites may be due to:

- the smaller size of the contaminated area;

- a reduced number of contaminants;

- the need for short-term solution of the pollution problems;

- the intervention in case of accidental spill;

- the absence of a significant volume of contaminated groundwater;

- the reduced technological knowledge;

- the absence of experimental test of their application in local site;

- the competitive costs expected for traditional techniques, etc..

A guidelines of APAT 2005a and 2005 b and Provincia di Milano 2006e can be used to verify the applicability and the results of in situ remediation.

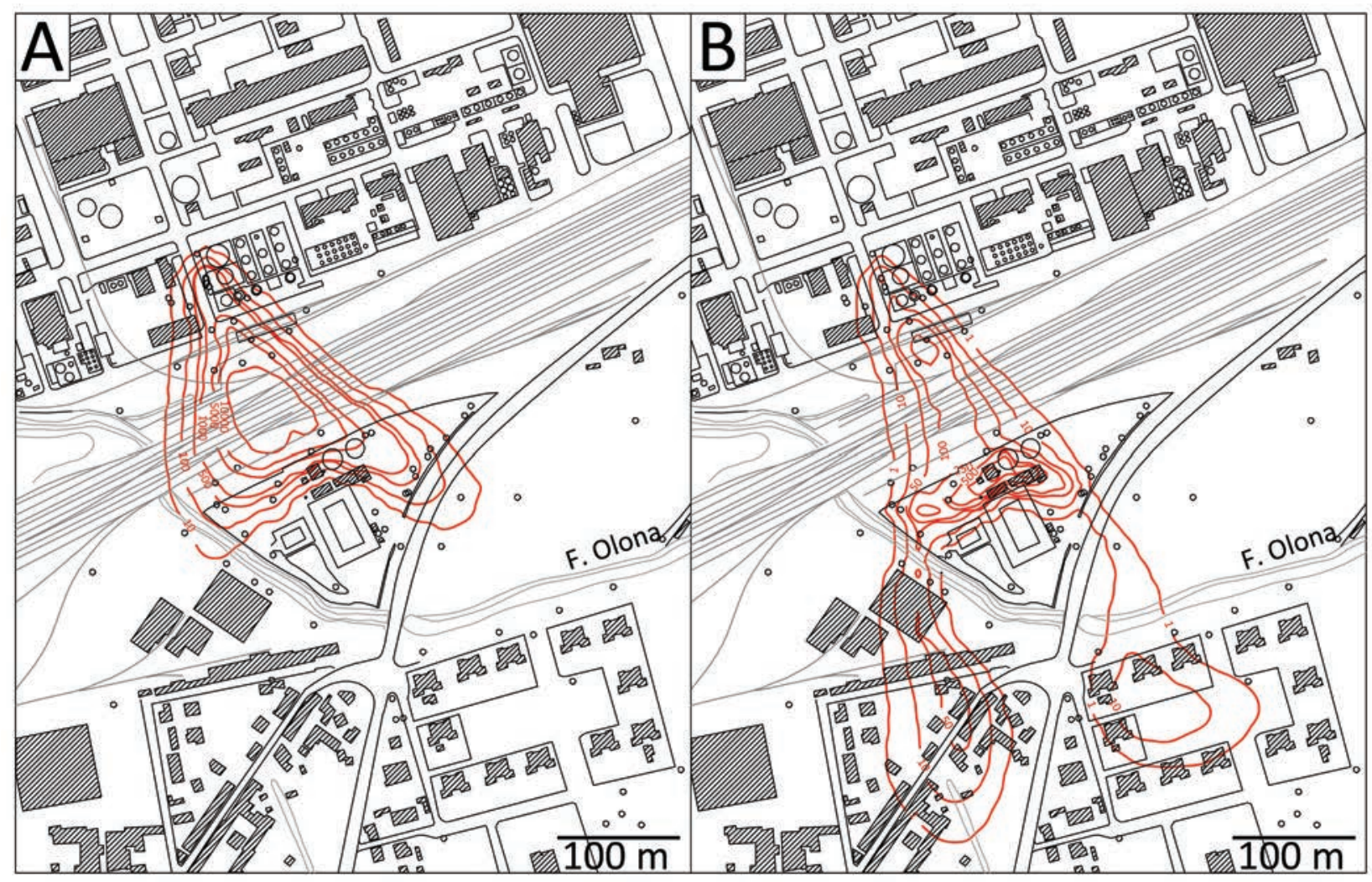

Fig. 6 - Isopleth maps of cyanides (A) and Hydrogen peroxide (B): values in $\mathrm{mg} / \mathrm{L}$.

Fig. 6 - Carta delle isocone di cianuri (A) e Perossido di idrogeno (B): valori in mg/L. 


\section{Summary and conclusions}

Dig and dump, vertical engineering barrier and hydraulic barrier (with pump \& treat) have required significant capital and O\&M costs, especially in SIN.

This has also led to a significant consumption of water resources in the face of a reduced mass of contaminant extracted.

Therefore, the application to these remedial measures at large scale has revealed a low efficiency and effectiveness, in relation to the expected environmental improvement, in the face of high costs, often due to the state of emergency.

In effect some emergency measures, made without an appropriate geological, hydrogeological and hydrochemical knowledge, have often anticipated and influenced the further remediation measures.

Therefore, in the recent time, the need to introduce new in situ techniques that tend to really break down the pollutant load, and reuse natural resources arose.

New technologies for the remediation of contaminated sites, already available at the international state of the art, have been applied in Italy, also with some but few original interventions.

In general, the site characterization requires many geological and hydrogeological data that can be processed with advanced methods such as geostatistics: a proper conceptual model is the basis of the subsequent processing of the data.

Furthermore the new approach has included flow and transport groundwater numerical modelling (finite difference or finite elements) used in the design.

The need for the application of in situ methods required the improvement of the instrumentation for the site characterization, such as active and passive soil gas survey, the flux chamber, the direct push techniques, the membrane interface probe, the flowmeter, the low flow purging, etc., with the integration of geophysical techniques.

In any case, some technical and economic elements have mainly influenced and limited the choices of the adopted method:

- the presence of screening values (table values) also considered as final target values of groundwater cleanup, and the difficulty to achieve them by the techniques even if highly performing;

- the need for a quick use of the urban areas, with high economic value per unit, without the constraints resulting from the adoption of remediation with emergency measures;

- the difficulty of using hot techniques (thermal desorption at low and high temperature, incineration);

- the slowness of the administrative process;

- the costs sustainable in the presence of brownfield sites.

Therefore, the achievement of the objectives of groundwater reclamation, notwithstanding the application of best available technology for long life, has not been achieved.
In fact, despite the recovery of the mass of pollutants even up to $90-99 \%$, they have not been achieved values of cleanup (expected concentrations of the order of $\mathrm{mg} / \mathrm{l}$ ) which are established by national legislation.

It can be stated that the scientific community is considering the new paradigm expressed by the "order of magnitude of the flow of pollutant mass" to replace the old paradigm consisting in the "limit value of final concentrations ".

Thus, the control of water quality and the monitoring of the natural attenuation of the residual concentrations and mass following a treatment in contaminated site assume considerable importance.

Finally, the hydrogeological knowledge governs the choice of the technology (with chemistry, biology and engineering) and especially the success of groundwater remedial actions. 


\section{REFERENCES}

American Society for Testing and Materials (1998). Standard guide for remediation of ground water by natural attenuation at petroleum release sites. ASTM E 1943-98. Conshohocken, Pennsylvania.

APAT (2005a). Protocollo per l'applicazione dell'ossidazione chimica in-situ. "Protocol to apply the in situ chemical oxidation". Agenzia per la Protezione dell'Ambiente e per i Servizi Tecnici. Servizio Interdipartimentale per le Emergenze Ambientali. Prot. N. 28220, Roma

APAT (2005b). Applicazione di tecnologie in situ per la bonifica delle acque sotterranee mediante l'iniezione di composti e reagenti chimici. "Application of in situ technologies for groundwater remediation by means of chemical compounds injection". Agenzia per la Protezione dell'Ambiente e per i Servizi Tecnici. Servizio Interdipartimentale per le Emergenze Ambientali, Settore Sistemi lntegrati Ambientali . Prot. N. 33360, Roma

APAT (2006a). Manuale per le indagini ambientali nei siti contaminati. "Handbook for contaminated sites characterization" Manuali e linee guida 43/2006, Roma

APAT (2006b). Proposta di integrazione del "Protocollo Operativo" per il campionamento e l'analisi dei siti contaminati- Fondo scavo e Pareti. "Proposal of integration of "Operating protocol" for sampling and analyze the contaminated sites. Bottom and walls of the excavation". Agenzia per la Protezione dell'Ambiente e per i Servizi Tecnici, Roma

Avanzini M., Beretta G.P., Fumagalli L., Pagotto A. (1994). In situ soil flushing method for soil and groundwater remediation of a Chromium $6^{+}$contaminated area in Brugherio (Milan, Italy). Second International Symposium and Exhibition on Environmental Contamination in Central and Eastern Europe, 20-23 September, Budapest

Avanzini M., Beretta G.P., Nespoli M., Pagotto A. (1996). Remedial Systems of Hydroxyisobutyronitrile Spill in Milano Area (Italy). $1^{\circ}$ Convegno Internazionale: L'impatto dell'attività industriale sulle risorse idriche sotterranee, 22-24 maggio 1996, Villa Erba, Cernobbio (Como)

Beretta G.P. (2013). Lo stato delle attività di bonifica in Italia. "The state of contaminated sites remediation in Italy". Atti SiCon 2013. Workshop su: Siti Contaminati. Esperienze negli interventi di risanamento, 21-23 Febbraio 2013, Roma

Beretta G.P., Bianchi M. (2004). In situ remediation of an Hexavalent Chromium contaminated site in Milan area (Italy) by soil flushing and geochemical fixation. Journal of technical \& environmental geology, Ottobre-Dicembre, 4/2004

Beretta G.P., Bianchi M., Pellegrini R. (2004) - Barriere idrauliche. "Hydraulc barriers". In: Bonifica di siti contaminati. Caratterizzazione e tecnologie di risanamento, A cura di L.Bonomo, McGrawHill

Beretta G.P., Nespoli M. (2006). Mega-efficacia della tecnologia soil vapor extraction nella bonifica da solventi clorurati di due mezzi insaturi sovrapposti presso l'area ex Acna a Cesano Maderno (Milano). "Mega effectiveness of soil vapour extraction for chlorinated solvents in two overlapping unsaturated media at the Cesano Maderno area (Milan)”. $2^{\circ}$ Congresso Nazionale A.I.G.A., 15-17 febbraio, Bari

Britton J.P. Filz G.M., Little J.C.(2002). Shape factors for single-well tests in soil bentonite cutoff wall. In: proceedings of $4^{\text {th }}$ International Congress on Environmental Geothecnics, ed. L.G. de Mello and M.Almeida, 639-644, Rio de Janeiro, Brazil, Balkema Publishers
Chini A., Franzino S., Pastore V., Veggi S. (2002). Il sito di interesse nazionale di Cengio e Saliceto $(\mathrm{SV}-\mathrm{CN})$ : criteri e modalità di controllo dei sistemi di confinamento. "The Sites of National Interest of Cengio and Saliceto: criteria and control methods for engineering barriers". Atti del Convegno "La bonifica dei siti contaminati: dall'esperienza in campo esempi di soluzioni alle problematiche", Milano 15 novembre 2002.

Choi H. (2007). Numerical model for analyzing slug tests in vertical cutoff walls. Journal of Geotechnical and Geoenvironmental Engineering, ASCE 133, no. 10, 1249-1258

Choi H., Daniel D.E. (2006a). Slug test analysis in vertical cutoff wall. 1:Analysis Method. Journal of Geotechnical and Geoenvironmental Engineering, ASCE 132, no. 4, 429-438

Choi H., Daniel D.E. (2006b). Slug test analysis in vertical cutoff wall. 1:Applications. Journal of Geotechnical and Geoenvironmental Engineering, ASCE 132, no. 4, 439-447

Commissario Delegato (2011). Dall'emergenza all'eccellenza. Bonifiche di Manfredonia 2010-2011. Casi di studio degli interventi di bonifica e messa in sicurezza permanente delle discariche di Pariti e Conte di Troia, nel Sito di Interesse Nazionale di Manfredonia (Fg). "From emergency to excellence. Remediation of Manfredonia 2010-2011. Cases study of remediation and adjective confinement of Pariti and Conte di Troia landfills in the Sites of National Interest of Manfredonia (FG)". A cura di Maurizio Croce e Alessandro Reina

Di Molfetta A., Sethi R. (2005). Bonifica di un acquifero contaminato mediante barriera reattiva permeabile a ferro zerovalente. "Remediation of contaminated aquifer through permeable reactive barrier with zerovalent iron”. MXV Congresso della Società Italiana di Ecologia, Torino

Di Molfetta, A., R. Sethi (2006). Clamshell excavation of a permeable reactive barrier. Environmental Geology vol. 50(3): 361-369

EIONET (2007 and 2014). Progress in management of contaminated sites. (CSI 015/LSI003)

European Communities (2000). Directive 2000/60/EC of The European Parliament and of the Council of 23 October 2000 establishing a framework for Community action in the field of water policy Official Journal of the European Communities, L327/1, 22.12.2000

Hellis D.E.,Hadley P.W. (2009). Sustainable remediation White Paper - Integrating Sustainable Principles, Practices, and Metrics Into Remediation Projects. Remediation, summer 2009

ISPRA (2003). Protocollo di valutazione dei risultati del monitoraggio di una barriera idraulica. "Protocol to evaluate the monitoring results of hydraulic barriers". Rev. 1, Istituto Superiore per la Protezione e la Ricerca Ambientale - Dipartimento Difesa del Suolo/ Servizio Geologico d'Italia, Roma

Kästner M., Brackevelt M., Döberl G., Cassiani G., Petrangeli Papini M., Leven-Pfister C., van Ree D. Eds (2012). MODEL-DRIVEN Soil probing, site assessment and evaluation - Guidance on technologies. ISBN 978-88-95814-72-8.

Landesanstalt für Umwelt, Messungen und Naturschutz BadenWürttemberg (2012). Ermittlung fachtechnischer Grundlagen zur Vorbereitung der Verhältnismäßigkeitsprüfung von langlaufenden Pump-and-Treat-Maßnahmen

Majone M., Rolle E., Petrangeli Papini M., Beretta G.P., Cicconi V., Maffucci M. (2009). Messa in sicurezza e bonifica di falde contaminate: un'analisi delle tecnologie impiegate a partire dall'applicazione del D.M. 471/99. "Emergency measures and remediation of contaminated groundwater: analysis of technology involved starting application of D.M. 471/99”. La Chimica e l'Industria, 2009 
Nguyen T.B. Lee S., Kim S., Choi H. (2010). Modification of the Bouwer and Rice Method to a Cutoff Wall with a Filter cake. Ground Water, Vol. 48, No. 6, 898-902

Pedretti D., Masetti M, Marangoni T, Beretta G.P. (2012). Slurry wall containment performance: monitoring and modeling of unsaturated and saturated flow. Environ. Monit. Assess. Jan;184(2):607-24

Petitta M. Pacioni E., Sbarbati C., Corvatta G., Fanelli M., Aravena R. (2012). Hydrodynamic and isotopic characterization of a site contaminated by chlorinated solvents: Chienti River Valley, Central Italy. Applied Geochemistry 32 (2013) 164-174

Provincia di Milano - Università degli studi di Milano (1999). Perimetrazione e caratterizzazione di un sito contaminato. "Perimeter and characterization of contaminated site". Linee Guida n.1

Provincia di Milano - Università degli studi di Milano (2003a). Linee guida per la verifica ed il collaudo delle barriere impermeabili per la messa in sicurezza di siti contaminati. "Guidelines to verify and to test of impermeable barriers for contaminated sites confinement". Linee guida n.4

Provincia di Milano - Università degli studi di Milano (2003b). Linee guida per la selezione di analiti da determinare nella caratterizzazione dei siti contaminati. "Guidelines to analytes selection in the contaminated sites characterization". Linee guida n.5

Provincia di Milano - Università degli studi di Milano (2003c). Linee guida per il monitoraggio delle barriere idrauliche. "Guidelines to monitoring hydraulic barriers". Linee guida n.6

Provincia di Milano - Università degli studi di Milano (2003d). Linee guida per la determinazione dei valori del fondo naturale nell'ambito della bonifica dei siti contaminati. "Guidelines to background values evaluation in the contaminated sites remediation”. Linee guida n.7

Provincia di Milano - Università degli studi di Milano (2004a). Linee Guida per il controllo e il monitoraggio di interventi di bonifica in situ. "Guidelines to control and monitoring the in situ remediation systems". Linee guida n.8

Provincia di Milano - Università degli studi di Milano (2004b). Linee Guida per il collaudo di scavi per interventi di bonifica on-site e off-site. "Guidelines for the test the dig for on-site and off-site remediation systems". Linee Guida n. 9

Provincia di Milano - Università degli studi di Milano (2006a). Linee Guida per l'utilizzo di strumenti e la selezione di strategie di campionamento delle matrici ambientali. "Guidelines for instrumentations use and selection of sampling strategies of environmental matrices". Linee guida n.10

Provincia di Milano - Università degli studi di Milano (2006b). Linee Guida per le strategie di campionamento e l'elaborazione statistica e geostatistica dei dati ambientali. "Guidelines for the sampling strategies and statistical and geostatistical environmental data processing". Linee guida n.11

Provincia di Milano - Università degli studi di Milano (2006c). Linee Guida per l'inertizzazione in situ dei suoli contaminati. "Guidelines for in situ contaminated soil inertisation”. Linee guida n.12

Provincia di Milano - Università degli studi di Milano (2006d). Linee Guida per interventi di bonifica mediante biopile e landfarming. "Guidelines for the interventions through biopile and landfarming”. Linee guida n.13

Provincia di Milano - Università degli studi di Milano (2006e). Linee Guida per la verifica del trattamento chimico in situ dei terreni e delle acque sotterranee. "Guidelines for the test the in situ chemical treatment of soil and groundwater". Linee guida n.14
Regione del Veneto (2007). "Trial field for the risk assessment of cross contamination through a natural barrier due to foundation pile construction-Porto Marghera". Manassero M., Dominijanni A.

Repubblica Italiana (2006). Norme in materia ambientale. "Rules in environmental matter". D. Lgs. 3 aprile 2006, n. 152, G.U. n.88 del 14 aprile 2006, Roma

Repubblica Italiana (2008). Ulteriori disposizioni correttive ed integrative del decreto legislativo 3 aprile 2006, n.152, recante norme in materia ambientale. "Further corrective and supplementary provisions of the legislative decree of 3 April 2006 n.152, containing rules on the environmental matter". D.Lgs. 16 gennaio 2008, n. 4. G.U. n. 24 del 29 gennaio 2008, Roma

Rossetti S., Aulenta F., Majone M., Tandoi V. (2008a). In situ molecular tracking of dehalogenating bacteria: from microbial enrichments to field samples. CONSOIL 2008, UFZ (Germany), TNO (The Netherlands), Provincia Di Milano (Italia), Milano

Rossetti S, Aulenta F, Majone M, Crocetti G, Tandoi V. (2008 b). Structure analysis and performance of a microbial community from a contaminated aquifer involved in the complete reductive dechlorination of 1,1,2,2-tetrachloroethane to ethane. Biotechnol Bioeng. Jun 1;100(2):240-9.

Shouakar-Stash O., Frape S. K., Aravena R., Gargini A., Pasini M., Drimmie R.J. (2009). Analysis of compound specific Chlorine stable isotopes of Vinyl Chloride by continuous Flow-Isotope Ratio Mass Spectrometry (FC-IRMS). Environmental Forensics, 10, 4, pp.299-306, DOI:

Teeter R.M., Clemence S.P. (1986). In-place permeability measurement of slurry trench cutoff walls. In proceedings of Use In Situ test in Geotechnical Engineering, ASCE, GSP No.6, ed. S.P.Clemence, 1049-1061, New York, ASCE

U.S. Environmental Protection Agency (1998). Evaluation of Subsurface Engineered Barriers at Waste Sites. EPA 542/R-98/005.

U.S. Environmental Protection Agency (1993). Quality Assurance and Quality Control for Waste Containment Facilities. EPA 600/R93/182.

U.S. Environmental Protection Agency (1992). Construction Quality Management for Remedial Action and Remedial Design Waste Containment Systems. EPA 540/R-92/073

U.S. Environmental Protection Agency (1995). Quality Assurance and Quality Control for Waste Containment Facilities. EPA/600/R-93/182. National Risk Management Research Laboratory, Cincinnati.

U.S. Environmental Protection Agency (1997). Use of Monitoring Natural Attenuation at Superfund, RCRA Corrective Action, and Underground Storage Tank Sites. Office of Solid Waste and Emergency Response Directive 9200.4-17

U.S. Environmental Protection Agency (1998). Evaluation of Subsurface Engineering Barriers at Waste Sites. EPA/542/R-98/005; Office of Solid Waste and Emergency Response, Washington.

U.S. Environmental Protection Agency (2006). Evaluation of the Role of Dehalococcoides Organisms in the Natural Attenuation of Chlorinated Ethylenes in Ground Water. National Risk Management Research Laboratory Office of Research and Development, Cincinnati, Ohio 